\title{
Meloxicam Elevates Serum Concentration of Erythropoietin and Numbers of Bone Marrow Erythroid Progenitor Cells in Sublethally Gamma-Irradiated Mice
}

\author{
Michal Hofer ${ }^{1}$, Milan Pospíšil ${ }^{1}$, Antonín Vacek ${ }^{1}$, Vladimír Znojil², Jiřina Holá ${ }^{1}$ \\ Denisa Štreitová ${ }^{1}$ \\ ${ }^{1}$ Institute of Biophysics, v.v.i., Academy of Sciences of the Czech Republic, Brno, Czech Republic \\ ${ }^{2}$ Institute of Pathological Physiology, Medical Faculty, Masaryk University, Brno, Czech Republic \\ Received February 25, 2008 \\ Accepted October 1, 2008
}

\begin{abstract}
Meloxicam, a non-steroidal anti-inflammatory drug selectively inhibiting cyclooxygenase-2, has been found to enhance the regeneration of erythroid progenitor cells (BFU-E) in the femoral bone marrow of mice when administered after sublethal irradiation (4 Gy gamma-rays). In mice treated with meloxicam once daily on days $3,4,5$, and 6 after irradiation, the values of BFU-E per femur in meloxicam-treated mice were on days 7 and 14 after irradiation at the levels of $156 \%$ and $191 \%$, respectively, related to those in irradiated saline-treated controls $(P<0.01$ and $P<0.001$, respectively). Moreover, it has been shown that these effects of meloxicam can be associated with its ability to stimulate erythropoietin production in irradiated mice. Six and 12 hours after one dose of meloxicam given on day 3 after irradiation, the serum level of erythropoietin was twofold higher in comparison with irradiated saline-treated controls $(P<0.05)$. These findings may have practical implications in the treatment of myelosuppression.
\end{abstract}

Cyclooxygenase-2 inhibition, erythropoiesis

Erythropoiesis is a complex process under the control of a number of factors like erythropoietin (EPO), stem cell factor (SCF), interleukin-11 (IL-11), and granulocyte colony-stimulating factor (G-CSF) (DeHaan et al. 1996). EPO is a crucial factor for the stimulation of erythropoiesis (Fisher 2003); for clinical treatment of anaemia, EPO (Kendall 2001) or synthetic darbepoietin-alpha are usually used, having a longer terminal half-life (Overbay and Manley 2002).

Inhibitors of prostaglandin production, known also as non-steroidal anti-inflammatory drugs (NSAIDs), which act on the principle of non-selective inhibition of cyclooxygenases, have been successfully tested as stimulators of suppressed haematopoiesis in a number of animal studies (for a review see Hofer and Pospíšil 2006). Although the vast majority of the findings concerns stimulatory effects of non-selective NSAIDs in the compartments of developing white blood cells, one study reports also an up-regulation of rat bone marrow erythropoiesis by these drugs (Kalaidjieva 1999). Recently we have published the results of a study testing the effectiveness of meloxicam, a NSAID belonging to selective cyclooxygenase-2 (COX-2) inhibitors developed for reducing the risks ensuing from undesirable gastrointestinal effects of non-selective NSAIDs (Lanas et al. 2003), in the treatment of radiation-suppressed mouse haematopoiesis. It follows from this study that meloxicam favourably influences not only granulopoiesis but also erythropoiesis of the experimental animals by increasing the numbers of granulocytic and erythroid progenitor cells (GM-CFC and BFU-E), as well as blood granulocytes and erythrocytes (Hofer et al. 2006). A consequential study aimed at clarifying the mechanism of the effects of meloxicam on granulopoiesis has revealed that meloxicam increases the blood serum levels of granulocyte colony-stimulating factor (G-CSF) in mice (Hofer et al. 2008). In this communication we show that post-irradiation administration of meloxicam to sublethally irradiated mice can enhance the counts of bone marrow erythroid progenitor cells and elevate serum concentration of EPO.

Address for correspondence:

MUDr. Michal Hofer, Ph.D.

Laboratory of Experimental Hematology

Institute of Biophysics, v.v.i.

Academy of Sciences of the Czech Republic

Královopolská 35, 61265 Brno, Czech Republic
Phone: +420541517 171

Fax: +420 541211293

E-mail: hofer@ibp.cz

http://www.vfu.cz/acta-vet/actavet.htm 


\section{Materials and Methods}

B10CBAF male mice weighing $30 \mathrm{~g}$ on average were used. Their use and treatment followed the European Community Guidelines. The experiments were performed with the approval of the Institute's Ethics Committee. Meloxicam (Sigma, St. Louis, MO, USA) was diluted with saline and administered intraperitoneally in injections of $0.6 \mathrm{mg} /$ mouse in a volume of $0.2 \mathrm{ml}$. Saline was used for control injections. The mice were whole-body irradiated with a sublethal dose of $4 \mathrm{~Gy}$ of ${ }^{60} \mathrm{Co}$ gamma-rays (dose rate of $0.25 \mathrm{~Gy} / \mathrm{min}$ ). The total number of nucleated cells per femur was determined by means of a Coulter Counter (Model ZF, Coulter Electronics, UK). Erythroid progenitor cells (burst-forming units, BFU-E) were cultivated on methylcellulose. Haemoglobinized colonies were counted as BFU-E after 8-day incubation and the numbers of BFU-E per femur were calculated. Serum concentrations of EPO were determined using commercial ELISA kits (R\&D Systems, Inc., Minneapolis, USA). The assay had the sensitivity of $18.0 \mathrm{pg} / \mathrm{ml}$. The significance of differences was evaluated using the MannWhitney U test followed by the Holm's correction for multiple comparisons. The significance level was set at $P<0.05$.

\section{Results}

The results of the two experiments evaluating the effects of meloxicam on numbers of bone marrow erythropoietic progenitor cells BFU-E are summarized in Table 1. In Experiment 1, sublethally (4 Gy) irradiated mice were treated with meloxicam in a fourdose (one dose per day) regimen; the drug was given on days 3, 4, 5, and 6 after irradiation. On days 7 and 14 after irradiation, the values of BFU-E per femur in meloxicam-treated mice were at $156 \%$ and $191 \%$, respectively, related to those in irradiated saline-treated controls. Statistical processing revealed significance of both these differences. On day 21 after irradiation, the numbers of BFU-E per femur in the animals given meloxicam were still at $135 \%$ of control values but the difference was not significant. With the aim to assess whether meloxicam is able to enhance the numbers of bone marrow BFU-E also when the number of its doses is reduced, Experiment 2 was performed in which mice were administered two doses of the drug on days 3 and 5 after irradiation. It was found that the stimulatory effect of meloxicam on the numbers of BFU-E per femur is preserved; on day 7 after irradiation the values of BFU-E per femur in meloxicam-treated mice attained $159 \%$ of those in irradiated saline-treated controls $(P<0.01)$.

Table 1. Numbers of BFU-E in the femoral bone marrow of meloxicam-treated mice after 4 Gy $\gamma$-irradiation

\begin{tabular}{|c|c|c|}
\hline \multicolumn{3}{|c|}{ BFU-E per femur $\times 10^{3}$} \\
\hline Day after irradiation & $\begin{array}{c}\text { Irradiated saline-treated } \\
\text { control mice }\end{array}$ & Meloxicam-treated mice \\
\hline \multicolumn{3}{|c|}{} \\
\hline Experiment 1. Mice treated with meloxicam on days 3, 4, 5, and 6 after irradiation \\
\hline 7 & $7.74 \pm 0.52$ & $12.11 \pm 1.17^{* *}$ \\
\hline 14 & $10.53 \pm 0.69$ & $20.09 \pm 1.34^{* * *}$ \\
\hline 21 & $17.40 \pm 2.82$ & 1.99 \\
\hline \multicolumn{3}{|c|}{} \\
\hline Experiment 2. Mice treated with meloxicam on days 3 and 5 after irradiation \\
\hline 7 & $6.32 \pm 0.53$ & $10.04 \pm 1.06^{* *}$ \\
\hline
\end{tabular}

Values are given as means \pm SEM. The experiments were performed twice and the results were pooled. A total of 10 animals per group were used.

**, ***, $P<0.01$, and $P<0.001$, respectively, compared with irradiated saline-treated controls (Mann-Whitney $\mathrm{U}$ test). Number of BFU-E per femur in non-irradiated untreated controls: $23.73 \pm 1.58 \times 10^{3}$.

For determination of possible modulatory effects of meloxicam on serum concentration of EPO, a treatment scheme consisting of one dose of meloxicam given on day 3 after irradiation of the mice by the dose of 4 Gy was used. Serum samples were taken 6 or 12 $\mathrm{h}$ after the administration of meloxicam. The results obtained on serum EPO are shown in 
Table 2. Serum concentrations of EPO ( $\mathrm{pg} / \mathrm{ml})$ in 4 Gy-irradiated mice after administration of meloxicam in a single dose on day 3 after irradiation

\begin{tabular}{|c|c|c|}
\hline \multicolumn{3}{|c|}{ Non-irradiated control mice } \\
\hline \multicolumn{3}{|c|}{$48.3 \pm 18.1$} \\
\hline Time interval after injection $(\mathrm{h})$ & Saline-treated control mice & Meloxicam-treated mice \\
\hline 6 & $206.0 \pm 86.6^{*}$ & $433.1 \pm 87.6^{\#}$ \\
\hline 12 & $186.3 \pm 16.1^{*}$ & $421.4 \pm 82.6^{\#}$ \\
\hline
\end{tabular}

Mice were administered saline or meloxicam at a single dose on day 3 after irradiation. Serum concentration of EPO was determined 6 and $12 \mathrm{~h}$ after the injection. Data are given as means \pm S.E.M. Five animals per group were used.

* $-P<0.05$ vs. non-irradiated control mice; \# - $P<0.05$ vs. irradiated saline-treated mice.

Table 2. Irradiation itself caused an expressive and significant increase in the concentration of EPO in the serum to about $400 \%$ of that in untreated controls. This result is in agreement with previously reported findings (Krantz and Jacobson 1970). A single injection of meloxicam increased the EPO concentration to more than a double of those observed in irradiated saline-treated controls. This finding was obtained in both sampling time intervals and the differences between the meloxicam-treated and saline-treated mice were again significant.

\section{Discussion}

The findings presented in this communication extend our previously (Hofer et al. 2006) reported data on the protective and stimulatory effects of the COX-2 inhibitor meloxicam in irradiated mice and newly demonstrate the ability of meloxicam to increase the production of EPO and regeneration of erythroid progenitor cells when giving this drug under post-irradiation conditions. Mechanisms of these effects are yet to be analyzed. Thus, it remains to be established whether the originally postulated mechanism of stimulation of haematopoiesis by NSAIDs via suppression of production of negatively acting prostaglandins (Fontagné et al. 1980) includes the stimulation of G-CSF and EPO production, or whether the increased cytokine concentrations are independent of the influence of the drug on the metabolic pathway of prostaglandins. However, it should be noted that our pilot studies did not show any effects of meloxicam on the production of EPO in normal non-irradiated mice (data not given). Thus, it seems that meloxicam only supports the mechanisms of positive control of erythropoiesis activated by irradiation.

The fact that meloxicam stimulates both post-irradiation granulopoiesis and erythropoiesis, may be of interest also for clinical practice. Recently it has been emphasized by a panel of specialists that studies of radioprotectors for use prior to irradiation and of therapeutic agents for post-exposure treatment are highest priority research areas for radiological nuclear countermeasures (Pellmar et al. 2005). Utilization of the obtained results on the haematopoiesis-stimulating action of meloxicam may be also advisable in further studies aimed at alleviation of myelotoxicity resulting from cytotoxic chemotherapy during oncological treatments. The possibility of using NSAIDs devoid of their undesirable side effects for the treatment of both granulocytopaenia and anaemia might be of interest for medical practice.

\section{Meloxicam zvyšuje hladinu erytropoetinu a počet erytroidních progenitorových buněk kostní dřeně u myší subletálně ozářených gama paprsky}

Zjistili jsme, že meloxicam, nesteroidní antiflogistikum selektivně inhibující cyklooxygenázu-2, podaný po ozáření myší subletální dávkou (4 Gy gama paprsků), posiluje regeneraci erytroidních progenitorových buněk (BFU-E) v kostní dřeni femuru. U myší 
léčených meloxicamem 3., 4., 5. a 6. den po ozáření se počty BFU-E na femur nacházely na úrovni $156 \%$ a $191 \%$ ve srovnání s hodnotami u ozářených kontrol, jimž byl podán fyziologický roztok $(P<0,01$ a $P<0,001)$. Další pozorování ukázala, že zmíněný účinek meloxicamu může být spojen s jeho schopností stimulovat u ozářených myší produkci erytropoetinu. Šest a 12 hodin po jedné dávce meloxicamu podané 3. den po ozáření byla sérová koncentrace erytropoetinu dvojnásobná ve srovnání s ozářenými kontrolami $(P<0,05)$. Tyto nálezy mohou mít praktické uplatnění v léčbě útlumu kostní dřeně.

\section{Acknowledgement}

This work was supported by the Grant Agency of the Czech Republic (grant No. 305/08/0158), the Academy of Sciences of the Czech Republic (grants No. AV0Z50040507 and AV0Z50040702), and the Grant Agency of the Academy of Sciences of the Czech Republic (grant No. 1QS500040507).

\section{References}

Dehaan G, Dontje B, Nijhof W 1996: Concepts of hemopoietic cell amplification. Synergy, redundancy and pleiotropy of cytokines affecting the regulation of erythropoiesis. Leuk Lymphoma 22: 385-394

Fisher JW 2003: Erythropoietin: physiology and pharmacology update. Exp Biol Med (Maywood) 228: 1-14

Fontagné J, Adolphe M, Semichon M, Zizine L, Lechat P 1980: Effect of in vitro treatment with indomethacin on mouse granulocyte-macrophage colony-forming cells in culture (CFUC). Possible role of prostaglandins. Exp Hematol 8: 1157-1164

Hofer M, Pospíšil M 2006: Stimulated recovery of perturbed haematopoiesis by inhibition of prostaglandin production - promising therapeutic strategy. Cent Eur J Biol 1: 584-593

Hofer M, Pospíśil M, Znojil V, Holá J, Vacek A, Štreitová D 2008: Meloxicam, an inhibitor of cyclooxygenase-2, increases the level of serum G-CSF and might be usable as an auxiliary means in G-CSF therapy. Physiol Res 57: $307-310$

Hofer M, Pospíšil M, Znojil V, Holá J, Vacek A, Weiterová L, Štreitová D, Kozubík A 2006: Meloxicam, a cyclooxygenase-2 inhibitor, supports hematopoietic recovery in gamma-irradiated mice. Radiat Res 166: 556-560

Kalaidjieva V 1999: Modulation of erythropoiesis in rat bone marrow erythroblastic islands by cyclooxygenase inhibition. Gen Pharmacol 32: 423-428

Kendall RG 2001: Erythropoietin. Clin Lab Haematol 23: 71-80

Krantz SB, Jacobson LO 1970: Effect of X-ray and drugs on renal control of erythropoietin production. In: Erythropoietin and the regulation of erythropoiesis. The University of Chicago Press, Chicago, pp. 36-39

Lanas A, Panés J, Piqué JM 2003: Clinical implications of COX-1 and/or COX-2 inhibition for the distal gastrointestinal tract. Curr Pharm Design 9: 2253-2266

Overbay DK, Manley HJ 2002: Darbepoietin-alpha: A review of the literature. Pharmacotherapy 22: 889-897

Pellmar TC, Rockwell S: Radiological/Nuclear Threat Countermeasures Working Group 2005: Priority list of research areas for radiological nuclear threat countermeasures. Radiat Res 163: 115-123 